\title{
Recording of Weathering Profile Development by Uranyl-Phosphate Minerals
}

\author{
MÁrio A. GonçAlves ${ }^{1}$, André Pinto ${ }^{2}$, José Mirão 3 \\ ${ }^{1}$ Dep. Geologia and IDL, Faculdade de Ciências Universidade \\ de Lisboa, Lisboa, Portugal; \\ mgoncalves@ciencias.ulisboa.pt \\ ${ }^{2}$ Department of Applied Geosciences, GUtech, Muscat, \\ Sultanate of Oman; andrefilipe.pinto@gutech.edu.om \\ ${ }^{3}$ HERCULES and Dep. Geociências, Universidade de Évora, \\ Évora, Portugal; jmirao@uevora.pt
}

The Nisa granitic massif in Central Portugal hosts several scattered uranium mineralizations, including the Nisa deposit, the largest known uranium reserve hosted by metamorphosed contact sediments [1]. Mineralization is characterized by uranyl-phosphate minerals resulting from the development of a weathering front that is several meters deep. Torbernite $(\mathrm{Cu})$ is the most abundant uranyl-phosphate in the granitic massif, variably substituted by uranocircite $(\mathrm{Ba})$ in some areas [2]. Torbernite may also be replaced by iron oxyhydroxides [2]. Other areas show relatively pristine torbernite crystals, such as those found in the centre of the massif. As we move outside the granitic massif into the metassediments, the major uranyl-phosphate becomes saleeite $(\mathrm{Mg})$ and minor autunite (Ca). These minerals may also sometimes be replaced by uranocircite [1].

These uranyl-phosphate minerals primarily record the geochemical background environment where they form and the development of the weathering front. Short-length drill cores show that uraninite and sulphides occur at depth [1]. Therefore, experimental observations of torbernite and saleiite replacement by uranocircite [1,3] suggests that: i) first stage weathering of sulphides and uraninite provide the ingredients for torbernite precipitation, while saleeite is related to weathering of $\mathrm{Mg}$-bearing minerals such as chlorite and biotite [1]; ii) increasingly weathered feldspars may release $\mathrm{Ba}$ that promote the later substitution of torbernite and saleeite; iii) as weathering advances, local substitution of uranyl-phosphate minerals by iron oxy-hydroxides is observed. Such observations can be important to establish possible relations between uranyl-phosphate occurrences and weathering profile development, potentially serving as a proxy to the depth of primary mineralization.

Acknowledgments: FCT funding UIDB/50019/2020 IDL and UID/04449/2017 - HERCULES.

References: [1] Prazeres, C. et al., 2018, J Iberian Geol, 44: 497; [2] Pinto, A. et al., 2012, Chem Geol, 312-313:18; [3] Andrade M. et al., 2015, Comun Geol, 102: 27. 